\title{
Nutrients release from powder phonolite mediated by bioweathering actions
}

\author{
Laene de Fátima Tavares ${ }^{1}$. André Mundstock Xavier de Carvalho ${ }^{1}$. Luis Gustavo Brogliato Camargo ${ }^{1}$. \\ Samarina Gabriele de Fátima Pereira ${ }^{1}$. Irene Maria Cardoso ${ }^{2}$
}

Received: 26 September 2017 / Accepted: 16 January 2018 / Published online: 31 January 2018

(c) The Author(s) 2018. This article is an open access publication

\begin{abstract}
Purpose Silicate rock powders have been appointed as possible nutrient alternative sources which might enhance the agricultural sector sustainability. However, the application of those materials directly in soil presents as main limitations the low content and solubility of the mineral nutrient sources. In this perspective, the aim of the present study was to evaluate, in a bioweathering perspective, the conjunct application potential of phonolite with organic composts over the nutrients release in soil, as well as the production and nutrition of brachiaria grass (Urochloa decumbens). In addition, it was sought to assess the composting process effectiveness in improving the nutrient release from this rock.

Method An experiment was conducted with five treatments (control; enriched compost with powder rock at 10\%; mixed compost with powder rock at $10 \%$; solely powder rock; solely compost) and four repetitions.

Results The alternative sources positively influenced the productivity, as well as the $\mathrm{K}$ and $\mathrm{Si}$ contents at the aerial part of the brachiaria grass and the nutrient release in soil. However, the conjunct applications of powder phonolite with organic composts were the source which the best promoted the total nutrient biorelease to soil.

Conclusion Nevertheless, there was no evidence that the composting process promotes the phonolite bioweathering. On the other hand, the conjunct application of powder phonolite with organic composts, either as an initial component to the composting pile or additive to the stabilized composts, is a strategy which enhances the nutrient biorelease of the mineral source.
\end{abstract}

Keywords Rock powders $\cdot$ Composting $\cdot$ Potassium alternative sources $\cdot$ Phonolite

Laene de Fátima Tavares

laene.tavares@ufv.br; laenetavares@gmail.com

André Mundstock Xavier de Carvalho andre.carvalho@ufv.br

Luis Gustavo Brogliato Camargo gustavobrogliato@hotmail.com

Samarina Gabriele de Fátima Pereira samarina.pereira@ufv.br

Irene Maria Cardoso

irene@ufv.br

1 Federal University of Viçosa, Rio Paranaíba Campus. MG-230 Highway - Km 7, Rio Paranaíba, Minas Gerais, Brazil

2 Federal University of Viçosa, Viçosa Campus. Peter Henry Rolfs Av., Viçosa, Minas Gerais, Brazil

\section{Introduction}

Pastures represent the main food source to bovines in Brazil. According to the Brazilian agricultural census of 2006 (IBGE 2007), it is estimated that approximately 172 million hectares are explored as pastures. The use of large areas for pastures is a global reality, since approximately $26 \%$ of all planet area is designated to the cattle grazing (FAO 2006).

Although the importance of pastures to the Brazilian cattle rising, the country has about 30 million hectares of pastures in some level of degradation (MAPA 2016). Among the factor related to the pastures degradation, stands out the soil use with high susceptibility to erosion, the excessive grazing, and the inadequate management of soil fertility (Peron and Evangelista 2004; Li et al. 2013; Sattari et al. 2016). In pastures areas, the fertility management is usually done with low nutrient intake, as well as in systems with one forage specie, or not used in consortium with larger plants, 
to optimize the nutrient cycling (Alves Filho et al. 2003; Calil et al. 2016).

The low nutrient intake in these systems are directly linked to the reuse difficulties of animal manures in a property level (Cordell et al. 2009; Elser and Bennet 2011) and to the crescent cost of conventional soluble fertilizer, which represent frequently the main component of the production costs. This scenario of fertilizer cost raising, and consequently, the increase of the activity risk, is associated, among other factors, to the high external Brazilian dependence by these inputs. According to the Brazilian National Association to Fertilizers Diffusion (ANDA 2014), Brazil is the fourth largest fertilizer importer of the world, with more than $90 \%$ of all potassium chloride consumed imported, being susceptive to the international market prices and offers oscillations.

Moreover, the crescent demand by inputs acceptable to organic production systems has stimulated the search for alternative sources of nutrients to soil fertilization. Despite the strong food production rising in agroecological systems in the world, the animal origin products represent a small portion of the organic market (Willer et al. 2014). Brazil is one of the few developing countries which is increasing the production and exportation of organic bovine beef (Chander et al. 2011). However, this participation is found far below from the crescent demand by organic products of this sector.

Therefore, it is evident the need to seek alternatives to the soil fertility management aiming at the agricultural sector sustainability. According to Srivastava et al. (2016), to be more sustainable, agriculture should be highly resilient, potentially effective, economically feasible, environmentally correct, and socially just. Thus, among the options to enhance the agricultural sustainability, there is nutrient cycling optimization through the organic waste use (Elser and Bennett 2011) and the use of less expansive and locally available sources.

In this perspective, the composting process has a big applicability potential in agriculture for being a low-cost investment and for presenting high efficiency and speed at the nutrient cycling process of several organic wastes (Lim et al. 2016). It is estimated that in each year, a third of all food produced in the world to human consumption is lost or wasted before being consumed (FAO 2011). Besides this, the agricultural sector produces high amounts of animal manures, and frequently does not reused. According to Cordell et al. (2009), on the 2000s, more than 7 million tons of phosphorus were released annually in the environment through animal manures, likely to cause serious environmental problems.

According to Guelfi-Silva et al. (2013), there is still the possibility of using residues from other productive sectors, such as the silicate powder rocks originated from mining subproducts. Although there is no global estimative of the subproducts quantity generated by the mining industry, in 2014, only the European Union produced 2503 million tons of mining wastes (Euro Stat 2017). In Brazil, it is estimated that in 2030, about 684 million tons of waste, originated from the mining sector, will be generated (IPEA 2012).

Despite the benefits of silicate powder rock application directly in soil, it presents as main limitation the low solubility and reactivity of the mineral sources of nutrients. In this way, the use of composting as means of bioweathering might optimize the reuse either of organic wastes or inorganic, resulting in an improvement at the final quality of produced composts.

Phonolite is a type of silicate rock which presents in its mineralogical composition the predominance of potassium feldspars and feldspathoids. Although its utilization as a fertilizer being appointed as promising, there is no evaluation of this rock in a bioweathering perspective in Brazil up to this moment. Thus, the aim of the present study was to evaluate the conjunct application potential of phonolite with organic composts, over the nutrient release in soil, as well as the production and nutrition of brachiaria grass. In addition, it was sought to assess the composting process effectiveness in improving the nutrient release of this rock.

\section{Materials and methods}

An experiment was conducted under field conditions at the experimental station of the Federal University of Viçosa (UFV), Rio Paranaíba campus, and state of Minas Gerais, located at the coordinates $19^{\circ} 12^{\prime} 35^{\prime \prime} \mathrm{S}$ and $46^{\circ} 7^{\prime} 57^{\prime \prime} \mathrm{W}$ at $1.125 \mathrm{~m}$ of altitude. The local's climate is classified as Cwa, according to Köppen-Geiger, presenting an average annual temperature of $20.4{ }^{\circ} \mathrm{C}$ and average annual rainfall of $1553 \mathrm{~mm}$. The soil of the experimental area was classified as a Typic Haplustox soil (Soil Survey Staff 2014).

\section{Experimental matrix}

The experiment was conducted in a randomized block design with five treatments (control; enriched compost with powder rock at $10 \%$; mixed compost with powder rock at $10 \%$; solely powder rock; solely compost) with four repetitions. The test crop used was a brachiaria grass (Urochloa decumbens), settled in the area at approximately ten years, and managed without irrigation, as well as fertilization, liming and use of agrochemicals after its implementation. The experimental units were constituted by $9 \mathrm{~m}^{2}$ zones $(3 \mathrm{~m} \times 3 \mathrm{~m})$. The composts and powder rock were applied at the dose equivalent to 33 and $5.4 \mathrm{t} \mathrm{ha}^{-1}$, respectively. 


\section{Composts' obtainment}

The composts were prepared in a partnership with BIOMIX-Industry and Commerce of Organic Inputs Ltda., located at the city of Cotia, São Paulo state-through the mixture of sawdust, livestock manure and fruit pulp wastes, according to the industry's routine procedures. The enrichment of the composting piles occurred at the initial moment of the ingredient mixture, allowing the rock dust to pass through the entire process. The addition of powder phonolite-which has a diversified chemical composition with approximately $8 \%$ of $\mathrm{K}_{2} \mathrm{O}, 54 \%$ of $\mathrm{SiO}_{2}$, and $6 \%$ of $\mathrm{Na}_{2} \mathrm{O}$ to the organic material followed a $10 \%(\mathrm{w} / \mathrm{v})$ ratio.

The composting piles had a volume of $20 \mathrm{~m}^{3}$ and were kept in an open courtyard, under a semipermeable floor for 90 days, until the composts maturation. For the mixed composts, the same procedure took place, but the addition of the powder rock occurred after the composting process stabilization, in other words, with the composts already maturated.

After the composts obtainment, those were led to the experimental station at UFV, dried, sieved in a $0.5 \mathrm{~mm}$ mesh sieve, and chemically characterized, according to Silva (2009) (Table 1). For the application of enriched compost and obtainment of the mixed compost, it was considered the materials density, so that minimizing the organic fraction dilution effect by the rock addition.

\section{Assessments}

The forage production was evaluated by cutting the aerial part, at four successive growth cycles of approximately 21 days. For sampling the aerial part of the biomass, a $0.25 \mathrm{~m}^{2}$ metal template was thrown four times in each useful zone, with cutting height of about $10 \mathrm{~cm}$. After the cutting of each cycle, the zones were scrapped and rattled, to simulate the exportation of forage by grazing.

The aerial part collected was dried in a forced air circulation laboratory stove at $65{ }^{\circ} \mathrm{C}$ and sub-samples were grinded in a Wiley mill equipped with a $1.0 \mathrm{~mm}$ sieve. Then, the samples were submitted to nitroperchloric digestion according to Silva (2009), and to peroxidic digestion in $\mathrm{NaOH}$, according to Elliott and Snyder (1991). The Si and K contents were determined by molecular absorption spectroscopy and atomic emission spectroscopy (Elliott and Snyder 1991; Silva 2009). The nutrient content in the plant biomass was calculated by the multiplication between the contents and the dry matter of plants. At the end of the experiment, soil samples were collected with the assistance of a probe-type $50 \mathrm{~mm}$ PVC auger, at the $0-20 \mathrm{~cm}$ soil layer, air-dried, and sieved in a $2 \mathrm{~mm}$ sieve. The available $\mathrm{Si}$ in soil was extracted by the $0.5 \mathrm{~mol} \mathrm{~L}^{-1}$ acetic acid extractor and determined by molecular absorption spectroscopy by the blue method (Leite 1997). Na and K, extracted in a Melich 1 solution, at the ratio soil:extractor of $1: 10$, were determined by atomic emission spectroscopy, according to Donagema et al. (2011). The total biorelease was determined through the somatory of $\mathrm{K}$ and $\mathrm{Si}$ contents present in the forage dry matter and the total content bioavailable in soil at the end of the experiment. The total nutrient biorelease variable, for considering simultaneously the previous variables, nutrient accumulation in plants and the residual effect in soil, is of great interest and sensibility, because, as an index, incorporates principles from the multivariate statistics.

\section{Statistical analysis}

The data were submitted to the Hartley test, Jarque-Bera (Jarque and Bera 1980) and ESD generalized (Rosner 1990) to evaluation of variances homogeneity conditions, residual normality, and presence of outliers, respectively. Then, the data were submitted to variance analysis (ANOVA) and the averages were compared among them by the Student-Newman-Keuls (SNK) test at 5\% of probability.

\section{Results}

\section{Growth and nutrition availability to plants}

The composts addition positively influenced the forage dry matter of brachiaria grass, promoting an average increment of $27 \%$ when compared to the control (Fig. 1). However, this expressive gain on the forage productivity by the enriched compost, mixed and pure, did not statistically differ among each other. Moreover, the fertilization with in natura powder phonolite did not result in a statistically significant increase of the total forage dry matter production when compared to the control.

The $\mathrm{K}$ content on the brachiaria grass forage was significantly increased by the composts when compared to
Table 1 Compost chemical characterization

\begin{tabular}{lllllllllll}
\hline Composts & $\mathrm{C}$ & $\mathrm{N}$ & $\mathrm{C} / \mathrm{N}$ & $\mathrm{K}_{2} \mathrm{O}$ & $\mathrm{Mn}$ & $\mathrm{Cu}$ & $\mathrm{Na}$ & Ashes & $\begin{array}{l}\mathrm{pH} \\
\left(\mathrm{CaCl}_{2}\right)\end{array}$ & $\begin{array}{l}\mathrm{CEC} \\
\mathrm{Mmol} \mathrm{kg}^{-1}\end{array}$ \\
\hline Pure & 15.60 & 1.52 & 10.26 & 0.95 & 365.00 & 75.00 & 0.36 & 53.55 & 7.90 & 300.00 \\
Enriched at $10 \%$ & 12.90 & 1.52 & 8.48 & 1.05 & 405.00 & 64.00 & 1.28 & 59.32 & 7.90 & 320.00 \\
Mixed at $10 \%$ & 12.30 & 1.40 & 8.78 & 0.82 & 435.00 & 68.00 & 1.00 & 64.00 & 7.90 & 350.00 \\
\hline
\end{tabular}


Fig. 1 Total dry matter of forage production, in four cutting cycles, of brachiaria grass fertilized with enriched compost or mixed at $10 \%$ with powder phonolite, solely in natura powder phonolite and pure compost. Averages followed by the same letter do not differ among each other by the SNK test, at the 5\% probability level. Dispersion bars correspond to the standard error

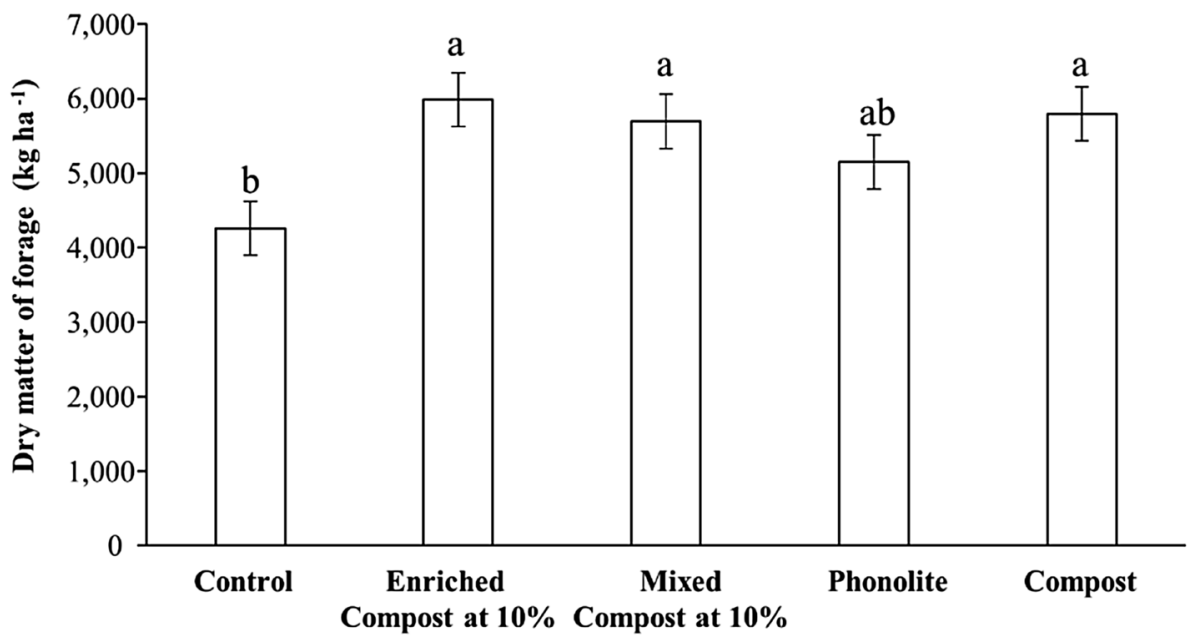

phonolite and the control treatment (Fig. 2a). However, all the evaluated alternative sources promoted increment at the Si content in a similar way, corresponding to approximately $64 \%$ in relation with the control (Fig. $2 b$ ).

\section{Releasement in soil and total nutrients biorelease}

The $\mathrm{K}$ and Si bioreleases in soil were clearly enhanced by the treatments (Fig. 3a, b). However, the difference between enriched compost and mixed at $10 \%$ with powder phonolite, to both elements evaluated, was not significant. Despite this,
Fig. 2 Potassium content (a) and Silicon (b) in the brachiaria grass forage fertilized with enriched compost or mixed at $10 \%$ with powder phonolite, solely in natura powder phonolite, and pure compost (average of four cuttings). Averages followed by the same lower case letter do not differ among them by the SNK test, at the 5\% probability level. Dispersion bars correspond to the standard error
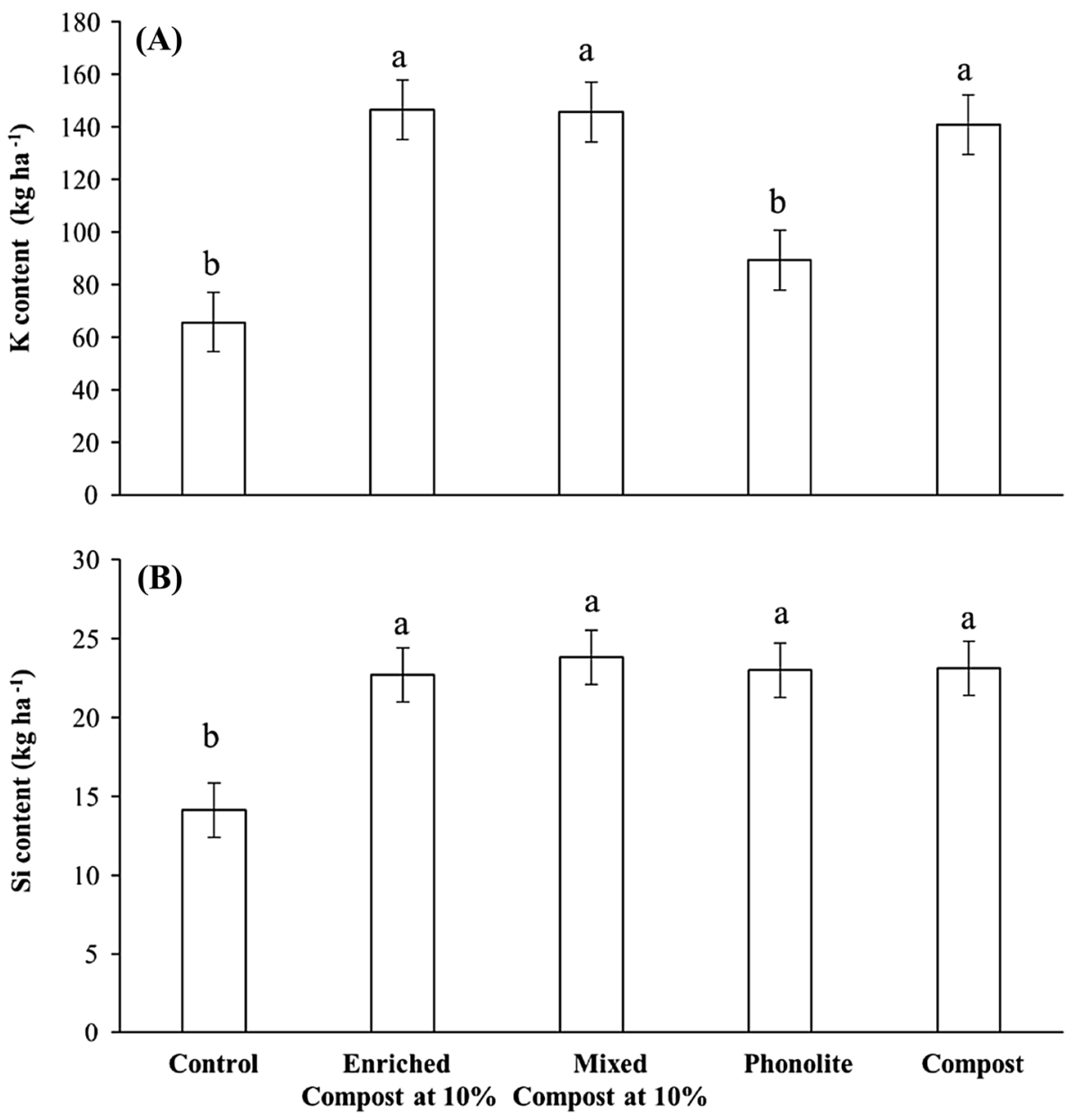
Fig. 3 Potassium (a), silicon (b) and sodium (c) availability in soil fertilized with enriched compost or mixed at $10 \%$ with powder phonolite, solely in natura powder phonolite and pure compost. Averages followed by the same lower case letter do not differ among them by the SNK test, at the 5\% probability level. Dispersion bars correspond to the standard error
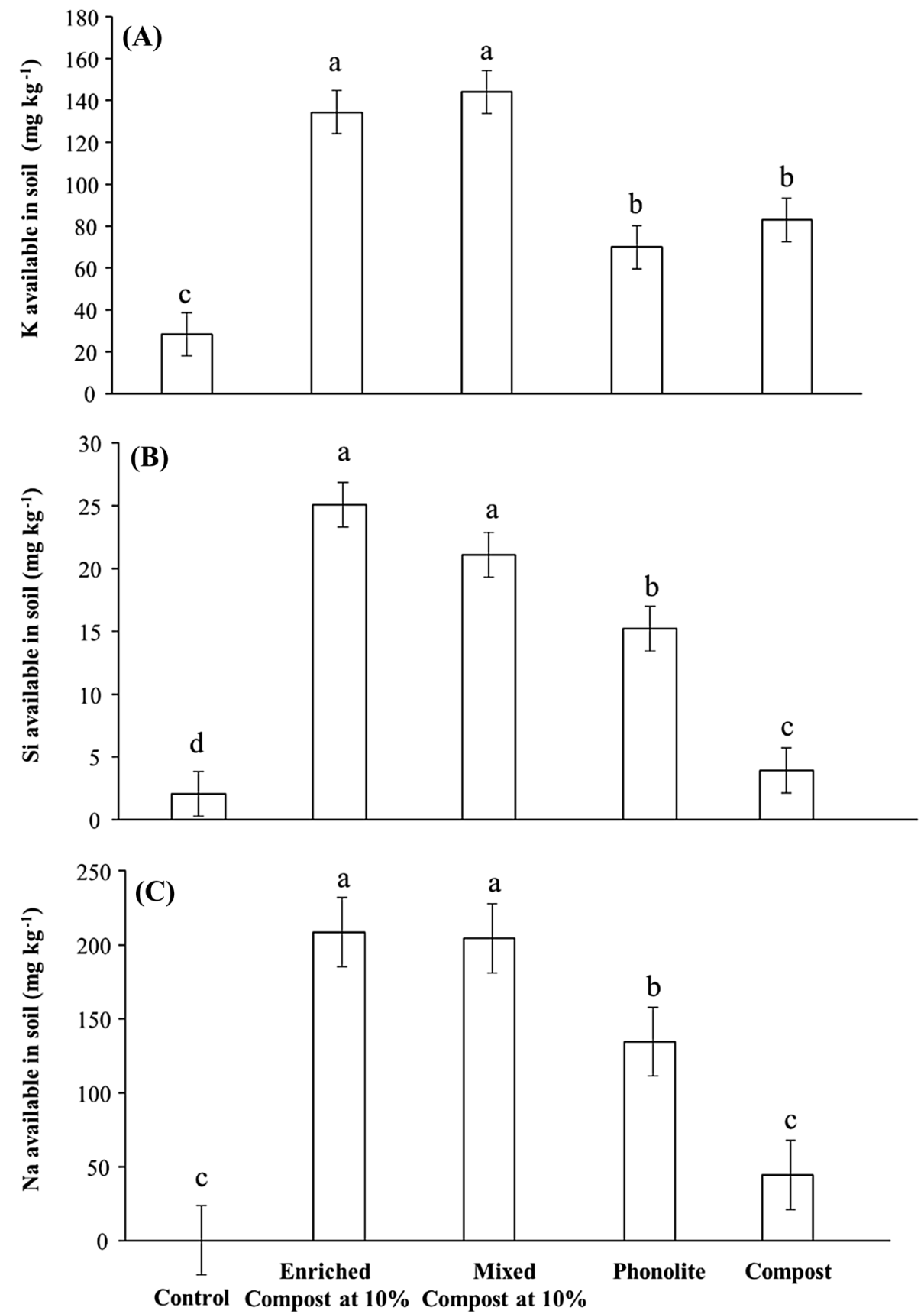

the use of powder phonolite in a conjunct form with organic compost, either by enrichment beforehand to the composting process or by the mixture after the bio-stabilization of the organic wastes, potentiated the $\mathrm{K}$ and $\mathrm{Si}$ releases of this silicate rock, providing a significant increase of these elements of approximately 68 and 486\%, respectively, when compared to the pure compost.

Fertilization with in natura powder phonolite considerably increased the $\mathrm{K}$ and $\mathrm{Si}$ releases in soil, promoting expressive increments in relation with the control and pure compost, respectively (Fig. 3a, b). Besides this, the phonolite also influenced the $\mathrm{Na}$ availability in soil, which was even more expressive when applied in a conjunct form with the organic composts (Fig. 3c).

The total $\mathrm{K}$ and $\mathrm{Si}$ bioreleases were clearly influenced by the treatments. The fertilization with organic compost in conjunction to powder phonolite potentiated the capacity of those fertilizers in releasing nutrients and promoting the brachiaria grass growth (Fig. 4a, b).

The composts used in association with the powder phonolite elevated the total $\mathrm{K}$ release in 38 and $169 \%$ when compared to the pure compost and to the powder phonolite, respectively. Moreover, these sources also substantially raised the Si releasement when compared to the effect 
Fig. 4 Potassium (a) and silicon (b) biorelease from enriched compost or mixed at $10 \%$ with powder phonolite, solely in natura powder phonolite and pure compost. Averages followed by the same lower case letter do not differ among them by the SNK test, at the 5\% probability level. Dispersion bars correspond to the standard error
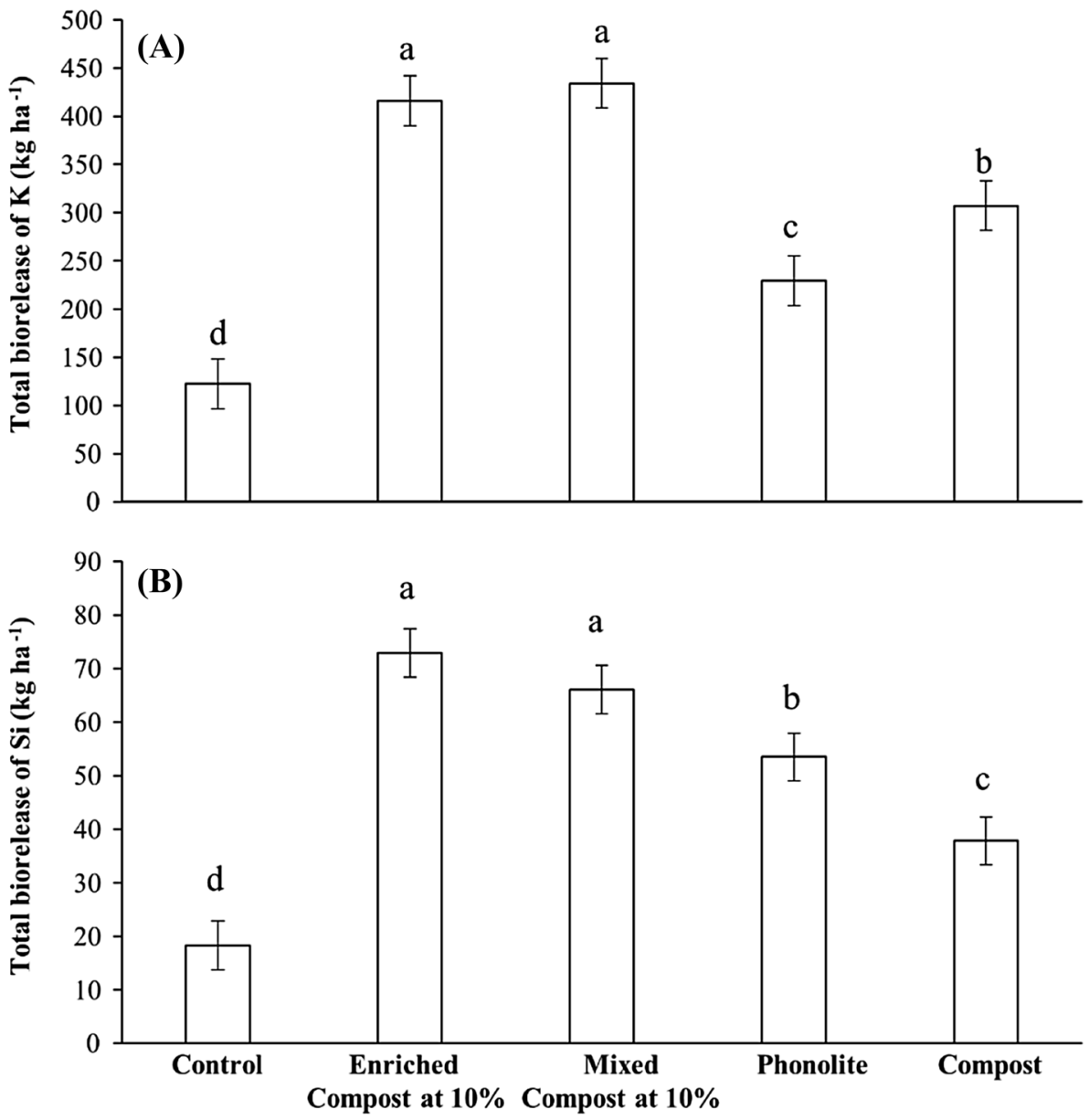

promoted by the fertilizers application separately. However, there was no statistical difference between the enriched and mixed compost treatments.

\section{Discussion}

\section{Brachiaria grass growth and nutrition}

The compost application substantially influenced the signal grass productivity when compared to the control (Fig. 1). This result demonstrates that the organic waste exploitation, either in a conjunct form with silicate sources or not, is an interesting option to pastures fertilization. Thus, the use of these organic materials might contribute both to the reduction of expansive soluble fertilizers dependence, largely responsible for the rancher's resistance in fertilizing grazing areas (Boddey et al. 2004), and to attend the crescent demand for fertilizers from the organic sector of production.

Dry matter content increments from the brachiaria grass forage, resulting from the application of $\mathrm{K}$ sources, were not significant if compared to the application of in natura powder rocks (Fig. 1). This fact suggests that other growing factor contributed to the forage production limitation, since that all composts expressively incremented the $\mathrm{K}$ content of the brachiaria grass aerial part when compared to the powder rock (Fig. 2a).

The $\mathrm{K}$ content rising at the brachiaria grass aerial part promoted by the composts (Fig. 2a) is probably related to the nutrient availability originated from the stabilized organic wastes. In this way, the presence of organic compost promoted, as expected, higher increments than the in natura powder phonolite, of lower solubility. However, by the increase observed at the treatment with only powder rock, even at the short period of evaluation, there is an expectation that in a medium-long term, better results could be observed. This hypothesis is supported by the data presented by Santos et al. (2016), which had responses to the verdete rock application solely in a medium term.

The composts where received powder phonolite incremented the $\mathrm{K}$ content in relation with the control treatment. However, the magnitude of this increment did not result in significant statistically differences when compared to the pure compost (Fig. 2a, b). This effect might be possibly linked to the $\mathrm{K}$ accumulation capacity by the crop, since that the releasement of this nutrient in soil was significantly 
improved when the composts were applied in conjunction with phonolite (Fig. 3a). In addition, this effect was verified by Orioli Júnior and Coutinho (2009), which observed that different sources improved the $\mathrm{K}$ availability in soil in a distinct manner, but did not differ regarding the $\mathrm{K}$ content at the Marandu grass aerial part.

Moreover, all composts and powder phonolite were capable in promoting the $\mathrm{K}$ content rising (data not shown) to values above the sufficiency range, reported by Carvalho et al. (1991). This result highlights the importance of residues exploitation in the nutrients management, contributing to the challenge of integrating and improving the agricultural and mining sectors sustainability. Besides this, regarding the dependence on soluble potassium sources, the effects promoted by the evaluated sources at the content of this element, also reflect in a greater autonomy of small farmers, considered the backbone's global food security (Horlings and Marsden 2011).

$\mathrm{Si}$ accumulation in tissues and cells is a prominent characteristic of plants from the Poaceae family (Melo et al. 2010). Despite this element does not be considered essential to plants development, there are several benefits of its application in crops of this family, such as the Urochloa gender. Sarto et al. (2016) verified that the brachiaria fertilization with $\mathrm{Si}$ positively influenced the efficiency in the water use and the $\mathrm{CO}_{2}$ assimilation rate of the crop, highlighting the relevance of the soil fertilization with this element.

At the present study, all evaluated potassium sources showed to be efficient in increasing the Si content in the brachiaria forage when compared to the control (Fig. 2b). However, the fertilizers evaluated did not differ among each other regarding the $\mathrm{Si}$ accumulation at the vegetable tissue. Moreover, it was observed that the increment magnitude of $\mathrm{Si}$ in the forage was small for a plant considered a silicon accumulator. According to Gunes et al. (2007), the Si accumulation at the aerial part is more expressive when the plants are susceptive to some kind of stress. This fact might explain the no difference between the tested sources more and less Si rich, since that the conditions were favorable to the crop development during all the experimental period.

\section{Nutrient release in soil and total biorelease}

The $\mathrm{K}$ alternative sources studied, besides of promoting the brachiaria grass growth, improved the $\mathrm{K}$ release in soil after the four pasture cutting (Fig. 3a). However, only the organic sources applied in a conjunct form with powder phonolite improved the nutrient level to values above $100 \mathrm{mg} \mathrm{kg}^{-1}$, which reaches the availability class considered "good" according to Ribeiro et al. (1999).

Despite the pure compost and powder phonolite application have result in significant $\mathrm{K}$ increments in soil, which passed from 28 to 83 and $70 \mathrm{mg} \mathrm{kg}^{-1}$, respectively, the observed increment is lower than the critic level of $\mathrm{K}$ in soil for some species from the Urochloa gender (Orioli Júnior and Coutinho 2009). Such fact demonstrates that the fertilization in soil with powder phonolite concomitantly with organic compost, either by an enrichment beforehand to the composting process, or by the simple mixture after the organic wastes stabilization, is capable of potentiating the nutrient release, promoting a considerable residual effect of $\mathrm{K}$ in soil (Fig. 3a).

The significant residual effect of $\mathrm{K}$ promoted, principally by the bioweathering action of the conjunct application of powder phonolite and organic compost, demonstrates that the lower reactivity of silicate sources might cooperate for the cation losses reduction, such as potassium, by the leaching process (Duarte et al. 2013). Besides of the K release takes place in a gradual form, the companion ion of low content and solubility mineral sources is silicate anions, known to be susceptive to specific adsorption by soil oxidic minerals, which contributes to the lower vertical mobility of potassium to depths beyond those occupied by roots. Furthermore, this effect also reflects that the capacity of the silicate powder rocks has in improving the soil cation-exchange capacity (CEC), minimizing $\mathrm{K}$ losses and other cations via leaching processes (Duarte et al. 2013).

The fertilization using Si sources has been more widely widespread due to the benefits which this element promotes in the development of several crops (Ma and Yamaji 2006). According to Korndörfer et al. (2002), soils which present Si concentration below $20 \mathrm{mg} \mathrm{kg}^{-1}$ need to be fertilized with this element. At the present study, the enriched or mixed organic sources with powder phonolite considerably raised the $\mathrm{Si}$ availability when compared to the other treatments. However, the enriched compost was the only source capable of increasing the Si availability above $20 \mathrm{mg} \mathrm{kg}^{-1}$ after the four pasture cuttings.

In natura application of powder phonolite also resulted in a significant $\mathrm{Si}$ increment in soil, which passed from 2 to $15 \mathrm{mg} \mathrm{kg}^{-1}$, although much lower when applied in a conjunct form with organic compost. Thus, it was observed that the Si release in soil, promoted by powder phonolite, followed a distinct tendency from the observed to the $\mathrm{Si}$ content at the forage aerial part. Similar result was reported by Orioli Júnior and Coutinho (2009), suggesting that the $\mathrm{Si}$ accumulation in this forage is either not so expressive or controlled not only by the availability in soil.

The bioweathering action stimulated by the conjunct application of powder phonolite with organic compost also favored the sodium releasement in relation with the other treatments (Fig. 3c). This result clearly evidences that the major presence of organic matter positively influences the rock's weathering, even with a probable different release rate by each element. It should be emphasized, however, that excessive quantities of soluble salts at the rizospheric 
region might reduce the $\mathrm{K}$ absorption, induce osmotic stress and cause toxicity to the plant (Wakeel 2013).

In this way, the increase of sodium verified at the present study suggests that the application of continue high doses of phonolite, mainly under this bioweathering perspective, might result in an undesirable accumulation of sodium in soil. Although the importance of this concern, Machado (2016) demonstrated that the Na accumulation in soil fertilized with high doses of phonolite can be easily controlled with the conjunct application of agricultural gypsum.

The total biorelease data are the parameter that best reflects the synthesis of the previous results, because it considers the magnitude of increments generated in the content in plants and the content still available in soil at the end of the experimental period. All the alternative sources evaluated were efficient in releasing nutrients in relation with the control. However, the $\mathrm{K}$ increment promoted by the organic composts combined with powder phonolite, both enriched and mixed, was substantially higher than the generated by pure compost or powder phonolite (Fig. 4a, b). This result corroborates with the data presented by Meena and Biswas (2014a), which verified improvements at the phosphorus supply capacity when organic sources were applied concomitantly with phosphorus powder rock.

Thus, it is verified that the management of low content and solubility alternative $\mathrm{K}$ sources, such as the silicate powder rock, can be significantly enhanced by conjunct application with organic residues. Besides the best use of nutrients retained in the mineral's crystalline structure, the conjunct application of powder phonolite with various organic wastes promotes benefits to the soil-plant system.

The improvement of the final quality of the produced composts with powder rock is possibly due to the abundant presence of microorganisms in the organic residues, which might support the nutrients solubilization present in minerals (Basak and Biswas 2009). Meena and Biswas (2014a), studying the effects of organic compost enrichment with phosphorus rocks, suggested that the significant increase of available $\mathrm{P}$ in soil is related to the production of organic acids by the microbial activity, such as citric acid, oxalic acid, and tartaric acid.

Beyond the range of microorganisms present in the organic compost itself, the fertilization is soil using rich sources in organic matter stimulates the development and the activity of microorganisms. For example, Bacillus mисіlaginosus is a common bacterium in soil, which presents high capacity in bioweathering $\mathrm{K}$ hold at the complex crystalline structure of minerals, such as micas, feldspars, and montmorillonite (Basak and Biswas 2009; Yang et al. 2016).

In this sense, the expressive increase of the $\mathrm{K}$ and $\mathrm{Si}$ biorelease from the composts with powder phonolite can be explained by the higher solubilization of minerals nutrient sources, through $\mathrm{pH}$ changes, promoted either by the microbial activity present in the composts organic fraction, as well as by the stimulation caused by the application of these composts to the microbiota in soil. According to Menna and Biswas (2014b), the fertilization of enriched composts with phosphorus powder rock and mica wastes improved the soil biological properties, such as microbial respiration, dehydrogenase activity, acidic, and alkaline phosphatase.

Soils with low CEC present high potential of K losses; reducing by this reason, the agronomic efficiency of fertilizers used (Hettiarachchi et al. 2014). Thus, the application of silicate powder rocks directly in tropical soil can promove potential increase of the soil CEC (Anda et al. 2009). In addition, the nature of composted materials, as well as the types of mineral enrichment of composts, might present an influence on humic substance generation (Lima et al. 2010), possibly affecting the soil CEC and, consequently, the nutrient dynamics. Therefore, besides the active mechanisms of organic acids exudation connected to the intense microbial activity, the highest total $\mathrm{K}$ release, propitiated by the composts with powder phonolite, might be a reflex of the CEC increase of these sources when compared to the pure compost. Such possibility is supported by Nishanth and Biswas (2008) and Lima et al. (2009), which observed expressive increase of the organic composts CEC that received mica residues.

It is important to stand out that, although there are some papers which aimed in evaluating the composting process effect over the weathering of low content and solubility mineral sources, those studies did not compare the enrichment effect beforehand the organic residues degradation with the simple mixture after the matured composts. At the present paper, the no detection of significant differences between enriched compost and mixed with powder phonolite suggests that the best capacity in promoting nutrients from these sources is due a synergic effect from the interaction of these materials, and not from the composting process itself.

\section{Conclusion}

There was no evidence that the composting process promoted the phonolite bioweathering. However, the conjunct application of powder phonolite with organic composts, either as an initial mixture component or additive to the stabilized composts, is a strategy that increases the nutrient release of the mineral source. Thus, the conjunct application of these subproducts is an alternative to the management of soil fertility, aiming the improvement of the agricultural sector sustainability. 
Acknowledgements We would like to thank to the Brazilian National Council for Scientific and Technological Development (CNPq) for the financial support and for Federal University of Viçosa, Brazil.

Open Access This article is distributed under the terms of the Creative Commons Attribution 4.0 International License (http://creativeco mmons.org/licenses/by/4.0/), which permits unrestricted use, distribution, and reproduction in any medium, provided you give appropriate credit to the original author(s) and the source, provide a link to the Creative Commons license, and indicate if changes were made.

\section{References}

Alves Filho DC, Neumann M, Restle J et al (2003) Características agronômicas produtivas, qualidade e custo de produção de forragem em pastagem de azevém (Lolium multiflorum Lam) fertilizada com dois tipos de adubo. Ciência Rural 33:143-149. https:// doi.org/10.1590/S0103-84782003000100023

ANDA (Associação Nacional para Difusão de Adubos) (2014) Anuário estatístico do setor de fertilizantes. http://www.anda.org.br/home. aspx. Accessed 10 Oct 2016

Anda M, Shamshuddin J, Fauziah CI, Omar SRS (2009) Dissolution of ground basalt and its effect on oxisol chemical properties and cocoa growth. Soil Sci 174:264-271. https://doi.org/10.1097/ SS.0b013e3181a56928

Basak BB, Biswas DR (2009) Influence of potassium solubilizing microorganism (Bacillus mucilaginosus) and waste mica on potassium uptake dynamics by sudan grass (Sorghum vulgare Pers.) grown under two Alfisols. Plant Soil 317:235-255. https://doi. org/10.1007/s11104-008-9805-z

Boddey RM, Macedo R, Tarré RM, Ferreira E, De Oliveira OC, Rezende CD, Cantarutti RB, Pereira JM, Alves BJ, Urquiaga S (2004) Nitrogen cycling in Brachiaria pastures: the key to understanding the process of pasture decline. Agric Ecosyst Environ 103:389-403. https://doi.org/10.1016/j.agee.2003.12.010

Calil FN, Lima NL, Silva RT et al (2016) Biomass and nutrition stock of grassland and accumulated litter in a silvopastoral system with Cerrado species. Afr J Agric Res 11:3701-3709. https://doi. org/10.5897/AJAR2016.11369

Carvalho MM, Martins CE, Verneque RD, Siqueira C (1991) Resposta de uma espécie de braquiária à fertilização com nitrogênio e potássio em um solo ácido. Rev Bras Ciência do Solo 15:195-200

Chander M, Subrahmanyeswari B, Mukherjee R, Kumar S (2011) Organic livestock production: an emerging opportunity with new challenges for producers in tropical countries. O I E Rev Sci Tech 30:969-983

Cordell D, Drangert JO, White S (2009) The story of phosphorus: global food security and food for thought. Glob Environ Chang 19:292-305. https://doi.org/10.1016/j.gloenvcha.2008.10.009

Donagema GK, Campos DVB, Calderano SB et al (2011) Manual de Métodos de Análise de Solos. Embrapa Solos, Rio de Janeiro

Duarte IN, Pereira HS, Korndörfer GH (2013) Lixiviação de potássio proveniente do termopotássio. Pesqui Agropecu Trop 43:195-200. https://doi.org/10.1590/S1983-40632013000200003

Elliott CL, Snyder GH (1991) Autoclave-induced digestion for the colorimetric determination of silicon in rice straw. J Agric Food Chem 39:1118-1119. https://doi.org/10.1021/jf00006a024

Elser J, Bennett E (2011) Phosphorus cycle: a broken biogeochemical cycle. Nature 478:29-31. https://doi.org/10.1038/478029a

EUROSTAT (2017) Statistical Office of the European Union. Waste statistics database. http://ec.europa.eu/eurostat/statisticsexplained/ index.php/Waste_statistics. Accessed 08 June 2017
FAO (2006) Livestock's long shadow: environmental issues and options. ftp://ftp.fao.org/docrep/fao/010/a0701e/a0701e.pdf

FAO (2011) Global food losses and food waste-Extent, causes and prevention. http://www.fao.org/docrep/014/mb060e/mb060e00. pdf

Guelfi-Silva DR, Marchi G, Spehar CR, Guilherme LR, Faquin V (2013) Agronomic efficiency of potassium fertilization in lettuce fertilized with alternative nutrient sources. Revista Ciência Agronômica 4:267-277. https://doi.org/10.1590/S1806-66902 013000200008

Gunes A, Inal A, Bagci EG, Coban S (2007) Silicon-mediated changes on some physiological and enzymatic parameters symptomatic of oxidative stress in barley grown in sodic-B toxic soil. J Plant Physiol 164:807-811. https://doi.org/10.1016/j.jplph.2006.07.011

Hettiarachchi RP, Dharmakeerthi RS, Seneviratne G et al (2014) Availability and leaching of nutrients after biofilm biofertilizer applications into a Red Yellow Podsolic soil. J Rubber Res Inst Sri Lanka 94:43-53

Horlings LG, Marsden TK (2011) Towards the real green revolution? Exploring the conceptual dimensions of a new ecological modernisation of agriculture that could "feed the world". Glob Environ Chang 21:441-452. https://doi.org/10.1016/j.gloen vcha.2011.01.004

IBGE (Instituto Brasileiro de Geografia e Estatística) (2007) Censo agropecuário 1920/2006. Estatística do Século XX. http://serie sestatisticas.ibge.gov.br/. Accessed 20 June 2017

IPEA (Instituto de Pesquisa Econômica Aplicada) (2012). Diagnóstico dos Resíduos Sólidos da Atividade de Mineração de Substâncias Não Energéticas. Relatório de Pesquisa. http://repositorio.ipea. gov.br/bitstream/11058/7702/1/RP_Diagn\%C3\%B3stico_2012. pdf

Jarque CM, Bera AK (1980) Efficient tests for normality, homoscedasticity and serial independence of regression residuals. Econ Lett 6:255-259. https://doi.org/10.1016/0165-1765(80)90024-5

Korndörfer GH, Pereira HS, Nolla A (2002) Silicatos de cálcio e magnésio na agricultura. GPSi-ICIAG-UFU, Uberlândia

Leite PC (1997) Interação silício-fósforo em latossolo roxo cultivado com sorgo em casa de vegetação. Dissertation, Federal University of Viçosa

Li XL, Gao J, Brierley G et al (2013) Rangeland degradation on the Qinghai-Tibet Plateau: implications for rehabilitation. L Degrad Dev 24:72-80. https://doi.org/10.1002/ldr.1108

Lim SL, Lee LH, Wu TY (2016) Sustainability of using composting and vermicomposting technologies for organic solid waste biotransformation: recent overview, greenhouse gases emissions and economic analysis. J Clean Prod 111:262-278. https://doi. org/10.1016/j.jclepro.2015.08.083

Lima CC, Mendonça ES, Silva IR et al (2009) Caracterização química de resíduos da produção de biodiesel compostados com adição mineral. Eng Agrícola e Ambient 13:334-340. https://doi. org/10.1590/S1415-43662009000300016

Lima CC, Mendonça EDS, Roig A (2010) Contribution of humic substances from different composts to the synthesis of humin in a tropical soil. Rev Bras Ciência do Solo 34:1041-1048. https:// doi.org/10.1590/S0100-06832010000400004

Ma JF, Yamaji N (2006) Silicon uptake and accumulation in higher plants. Trends Plant Sci 11:392-397. https://doi.org/10.1016/j. tplants.2006.06.007

Machado LG (2016) Características químicas do solo, produtividade e nutrição de café e capim braquiária fertilizados com pó de fonolito e termopotássio. Dissertation, Federal University of Viçosa

MAPA (Ministério da Agricultura Pecuária e Abastecimento) (2016) Recuperação de Áreas Degradadas. http://www.agricultura.gov. br/desenvolvimento-sustentável/recuperacao-areas-degradadas. Accessed 31 Aug 2016 
Meena MD, Biswas DR (2014a) Phosphorus and potassium transformations in soil amended with enriched compost and chemical fertilizers in a wheat-soybean cropping system amended with enriched compost and chemical. Commun Soil Sci Plant Anal. https://doi.org/10.1080/00103624.2013.867044

Meena MD, Biswas DR (2014b) Changes in biological properties in soil amended with rock phosphate and waste mica enriched compost using biological amendments and chemical fertilizers under wheat-soybean rotation. J Plant Nutr. https://doi. org/10.1080/01904167.2014.920368

Melo SP, Monteiro FA, de Bona FD (2010) Silicon distribution and accumulation in shoot tissue of the tropical forage grass Brachiaria brizantha. Plant Soil 336:241-249. https://doi.org/10.1007/ s11104-010-0472-5

Nishanth D, Biswas DR (2008) Kinetics of phosphorus and potassium release from rock phosphate and waste mica enriched compost and their effect on yield and nutrient uptake by wheat (Triticum aestivum). Bioresour Technol 99:3342-3353. https://doi.org/10.1016/j. biortech.2007.08.025

Orioli Júnior V, Coutinho ELM (2009) Effectiveness of fused magnesium potassium phosphate for marandu grass effectiveness of fused magnesium potassium phosphate for marandu grass. Rev Bras Ciência do Solo 33:1855-1862. https://doi.org/10.1590/ S0100-06832009000600034

Peron AJ, Evangelista AR (2004) Pasture degradation in savanna's regions. Ciênc Agrotec 28:655-661. https://doi.org/10.1590/ S1413-70542004000300023

Ribeiro AC, Guimarães PT, Alvarez VH (1999) Recomendações para o uso de corretivos e fertilizantes em Minas Gerais- $5^{\text {a }}$ Aproximação. Comissão de fertilidade do solo do Estado de Minas Gerais, Viçosa

Rosner B (1990) Percentage points for a generalized ESD many-outlier procedure. Technometrics 25:165-172

Santos WO, Mattiello EM, Vergutz L, Costa RF (2016) Production and evaluation of potassium fertilizers from silicate rock. J Plant Nutr Soil Sci 179:547-556. https://doi.org/10.1002/jpln.201500484
Sarto MVM, do Carmo Lana M, Rampim L et al (2016) Effects of silicon ( $\mathrm{Si}$ ) fertilization on gas exchange and production in $\mathrm{Bra}$ chiaria. Aust J Crop Sci 10:307-313. https://doi.org/10.21475/ ajcs.2016.10.03.p6864

Sattari SZ, Bouwman AF, Martinez Rodríguez R et al (2016) Negative global phosphorus budgets challenge sustainable intensification of grasslands. Nat Commun 7:10696. https://doi.org/10.1038/ ncomms 10696

Silva FC (2009) Manual de Análises Químicas de Solos, Plantas e Fertilizantes. Embrapa Informação Tecnológica, Brasília

Soil Survey Staff (2014) Keys to soil taxonomy. United States Department of Agriculture, Natural Resources Conservation Service, Washington, DC

Srivastava P, Singh R, Tripathi S, Raghubanshi AS (2016) An urgent need for sustainable thinking in agriculture-An Indian scenario. Ecol Indic 67:611-622. https://doi.org/10.1016/j.ecoli nd.2016.03.015

Wakeel A (2013) Potassium-sodium interactions in soil and plant under saline-sodic conditions. J Plant Nutr Soil Sci 176:344-354. https ://doi.org/10.1002/jpln.201200417

Willer H, Lernoud J, Schlatter B (2014) Current statistics on organic agriculture worldwide: organic area, producers and market. The World of Organic Agriculture. Statistics and Emerging Trends 2014. FiBL-IFOAM Report, pp 36-124

Yang X, Li Y, Lu A et al (2016) Effect of Bacillus mucilaginosus D4B1 on the structure and soil-conservation-related properties of montmorillonite. Appl Clay Sci 119:141-145. https://doi.org/10.1016/j. clay.2015.08.033

Publisher's Note Springer Nature remains neutral with regard to urisdictional claims in published maps and institutional affiliations. 